\title{
Fungal monitoring of the indoor air of the Museo de La Plata Herbarium, Argentina
}

\author{
Andrea C. Mallo ${ }^{\mathrm{a}, e, *}$, Lorena A. Elíades ${ }^{\mathrm{b}, \mathrm{f}}$, Daniela S. Nitiu ${ }^{\mathrm{a}, \mathrm{f}}$, Mario C.N. Saparrat ${ }^{\mathrm{b}, \mathrm{c}, \mathrm{d}, \mathrm{f}}$ \\ a Cátedra de Palinología, Facultad de Ciencias Naturales y Museo, Universidad Nacional de La Plata, Argentina \\ ${ }^{\mathrm{b}}$ Instituto de Botánica Carlos Spegazzini, Facultad de Ciencias Naturales y Museo, Universidad Nacional de La Plata, Argentina \\ ' Instituto de Fisiología Vegetal, Argentina \\ d Cátedra de Microbiología Agrícola, Facultad de Ciencias Agrarias y Forestales, Universidad Nacional de La Plata, Argentina \\ e Comisión de Investigaciones Científicas de la Provincia de Buenos Aires (CIC-PBA), Argentina \\ ${ }^{\mathrm{f}}$ Consejo Nacional de Investigaciones Científicas y Tecnológicas (CONICET), Argentina
}

\section{A R T I C L E I N F O}

\section{Article history:}

Received 7 November 2014

Accepted 11 May 2016

Available online 15 February 2017

\section{Keywords:}

Biological collections

Fungal spores

Indoor airborne fungi

La Plata Herbarium

Viable and non-viable methods

\begin{abstract}
A B S T R A C T
Background: Biological agents, such as fungal spores in the air in places where scientific collections are stored, can attack and deteriorate them.

Aims: The aim of this study was to gather information on the indoor air quality of the Herbarium of Vascular Plants of the Museo de Ciencias Naturales de La Plata, Argentina, in relation to fungal propagules and inert particles.

Methods: This study was made using a volumetric system and two complementary sampling methods: (1) a non-viable method for direct evaluation, and (2) a viable method by culture for viable fungal propagules.

Results: The non-viable method led to ten spore morphotypes being found from related fungal sources. A total of 4401.88 spores $/ \mathrm{m}^{3}$ and 32135.18 inert suspended particles $/ \mathrm{m}^{3}$ were recorded. The viable method led to the finding of nine fungal taxa as viable spores that mostly belonged to anamorphic forms of Ascomycota, although the pigmented yeast Rhodotorula F.C. Harrison (Basidiomycota) was also found. A total count of 40,500 fungal $\mathrm{CFU} / \mathrm{m}^{3}$ air was estimated for all the sites sampled. Conclusions: Both the non-viable and viable sampling methods were necessary to monitor the bio-aerosol load in the La Plata Herbarium. The indoor air of this institution seems to be reasonably adequate for the conservation of vascular plants due to the low indoor/outdoor index, low concentrations of air spores, and/or lack of indicators of moisture problems.
\end{abstract}

(C) 2016 Asociación Española de Micología. Published by Elsevier España, S.L.U. All rights reserved.

\section{Muestreo de los hongos del aire en el interior del Herbario del Museo de La Plata, Argentina}

\section{R E S U M E N}

Antecedentes: Los agentes biológicos, tales como las esporas fúngicas suspendidas en el aire, en sitios donde se conservan colecciones científicas, pueden dar lugar al ataque y deterioro de las mismas por los hongos.

Objetivos: El objetivo de este trabajo fue proporcionar información acerca de la calidad del aire interior en el Herbario de Plantas Vasculares del Museo de Ciencias Naturales de La Plata, Argentina, en relación con el contenido de propágulos fúngicos y partículas inertes, mediante el uso de dos técnicas complementarias. Métodos: El estudio se llevó a cabo con un sistema volumétrico y dos metodologías de muestreo: 1) método no viable de evaluación directa; y 2) método viable para el cultivo de propágulos fúngicos viables.

Resultados: A partir del sistema de recuperación directa se cuantificó un total de 4401,88 esporas $/ \mathrm{m}^{3}$ con 10 morfotipos pertenecientes en su mayoría a anamorfos de Ascomycota. Asimismo se cuantificaron 32135,18 partículas inertes suspendidas por $\mathrm{m}^{3}$. Con el uso del sistema viable se estimó un total de $40.500 \mathrm{UFC} / \mathrm{m}^{3}$ aire para todos los sitios muestreados y se identificaron nueve taxa fúngicos

\footnotetext{
* Corresponding author.

E-mail address: malloa2001@yahoo.com.ar (A.C. Mallo).
} 
que pertenecen también a formas anamórficas de Ascomycota, aunque se halló la levadura pigmentada Rhodotorula F.C. Harrison (Basidiomycota).

Conclusiones: Ambos métodos, viable y no viable de muestreo, son necesarios para el control de la carga de aerosoles en el Herbario de La Plata. El aire interior de esta institución parece razonablemente adecuado para la conservación de plantas vasculares, dado el bajo índice interior/exterior, bajas concentraciones de esporas o la ausencia de indicadores de problemas de humedad.

(c) 2016 Asociación Española de Micología. Publicado por Elsevier España, S.L.U. Todos los derechos reservados.

Biodeteriogens like fungi, bacteria and Actinomycetes pose severe threat to biological collections, represent risk for human health, and are a cause of deterioration of different stored materials. ${ }^{5,14,38}$ Climatic and indoor environmental conditions such as temperature, humidity and air circulation influence the microbial prevalence. ${ }^{41}$ Microbes enter the indoor atmosphere through wind currents, and staff and visitors carry dust particles deposited by impaction. One of the main factors which influence indoor pollution levels is the outdoor air quality. ${ }^{25,29}$ Also, the indoor concentrations of fungal spores depend on both indoor and outdoor sources as well as on removal processes, such as air exchange and chemical reactions. ${ }^{33,36}$

Microorganisms can compromise the structure and function of the materials involved in biological collections in different ways. Fungi are an important cause of chromatic and structural alterations due to mycelial growth and pigment production, degrading cellulose and producing acids like oxalic, fumaric, succinic and acetic acid, which alter the normal $\mathrm{pH}$ of the substrate. ${ }^{20,21}$

Biological collections are of vital importance for cultural heritage worldwide since they constitute an invaluable source of scientific information. In this sense, numerous standardized protocols are applied at present to protect and maintain biological materials over time. ${ }^{47}$ Biodeterioration and biodegradation processes are problems that curators have to deal with nowadays. The monitoring and control of these agents that may colonize and degrade materials are critical measures for the safe preservation of this cultural heritage. Several studies about the prevalence and viability of microbial propagules in the air have been carried out. ${ }^{12,16,51}$ These studies are vital to have a detailed overview of the environmental air quality inside biological collections ${ }^{16}$ due to their usefulness as indicators of the conditions of conservation. The handling of biodeteriorated specimens is another serious problem for people's health since these microorganisms might be also pathogenic, allergenic and/or toxinogenic. ${ }^{27,35,45,46}$

The biological material stored in herbaria are mostly collections of dry botanic specimens, organized by a given system, classified by a phylogenetic and alphabetic order ${ }^{6}$ and preferably stored under controlled conditions for conservation. The specimens are mounted on cardboard and every material must be stored in cold $\left(-20^{\circ} \mathrm{C}\right)$ quarantine before incorporation. Then, they are transferred to special cabinets for preservation. One of the problems of conservation of these collections is related to the substrate, comprised by both the plant material (each specimen) and the support (cardboard), because both are rich in organic components for the development of insects, fungi and bacteria, which are important biodeterioration agents. ${ }^{34,51}$ Another problem of these collections is the phytosanitary conditions of the plant material itself. So, safety practices as the control of environmental conditions, people movement, and monitoring of the collections are standard measures to be taken.

The Museo de Ciencias Naturales de La Plata, Argentina (34 $55^{\prime} \mathrm{S}$, $57^{\circ} 57^{\prime} \mathrm{W}$ ) (Fig. $1 \mathrm{a}$ and b), houses the Herbarium of Vascular Plants (LP), which is an important institution containing significant collections of Asteraceae, Poaceae, Fabaceae and Pteridophyta (ca. 500,000 specimens). This institution is one of the largest in Latin America, and includes type material (5000 specimens) collected by famous botanists such as A. L. Cabrera and C. L. Spegazzini. ${ }^{19,26}$ Although the plant collection is properly preserved in special cabinets and with controlled handling of environmental conditions, there is no available information about the indoor air quality of this Herbarium.

Fungi have proved to be the most important biodeterioration agents, especially on supports made of cellulose, ${ }^{44}$ which is the main component of these plant collections. On the other hand, dust serves as a source of nutrients to some insects and fungi, and creates a microenvironment on collection surfaces, facilitating the absorption of moisture and promoting the proliferation of pests. ${ }^{13}$ For this reason, the aim of this work was to characterize both the indoor air mycobiota and the content of inert particles in the LP Herbarium, by using viable and non-viable volumetric methodologies.

\section{Material and methods}

\section{Study site}

The LP Herbarium, with a total surface of $350 \mathrm{~m}^{2}$ and ca. $1400 \mathrm{~m}^{3}$, has several workplaces (Fig. 1c), including areas for research and administration, and a main room where plant specimens are adequately preserved under standard protocols and controlled temperature and humidity conditions (Laura Iharlegui, personal communication). Taking into account the age of the building, the place where the collections are stored (sites I and II) is in good condition due to its regular maintenance. The working and circulation areas (sites IV and V) do not present visible deterioration, whereas the secondary entrance (III) is the most exposed site due to the staff movement and the direct connection with the exterior and the exterior corridor (VI). Six representative areas of the Herbarium were analyzed in this study: I - the main access to the Herbarium $\left(180 \mathrm{~m}^{3}\right)$, II - the central corridor $\left(43 \mathrm{~m}^{3}\right)$, III - the secondary entrance $\left(27 \mathrm{~m}^{3}\right), \mathrm{IV}$ - the visiting room $\left(41 \mathrm{~m}^{3}\right), \mathrm{V}$ - the lobby $\left(60 \mathrm{~m}^{3}\right)$, and $\mathrm{VI}$ - the exterior corridor (open space) (Fig. 1c).

\section{Sampling and data analysis}

The indoor air was sampled on December 21st, 2011, at 9:30 am. The collection room (sites I-II) has a central air conditioning system and a dehumidifier device to control temperature and humidity. These parameters were recorded using a HOBO U14 LCD data logger. At the moment of the sampling, the mean temperature and mean relative humidity $(\mathrm{RH})$ inside the collection site were $21.6^{\circ} \mathrm{C}$ and $53.5 \%$ respectively, while those outside were $27.5^{\circ} \mathrm{C}$ and $55 \%$ respectively. The study was performed during a period of recess of activities and absence of staff and visitors to reduce the effect of turbulence in the air.

The indoor air sampling was done on a volumetric Hirst type system with a Zefon Z-Lite IAQ Air Sampling Pump ${ }^{\circledR}$ by using two procedures: a non-viable and a viable method. In the non-viable method the pump was connected to the Air-O-Cell ${ }^{\circledR}$ cassette for direct microscopic evaluation of bioaerosols, whereas in the viable method a holder with a cellulose filter was connected to the same device to obtain a sample to culture viable fungal propagules. Both 


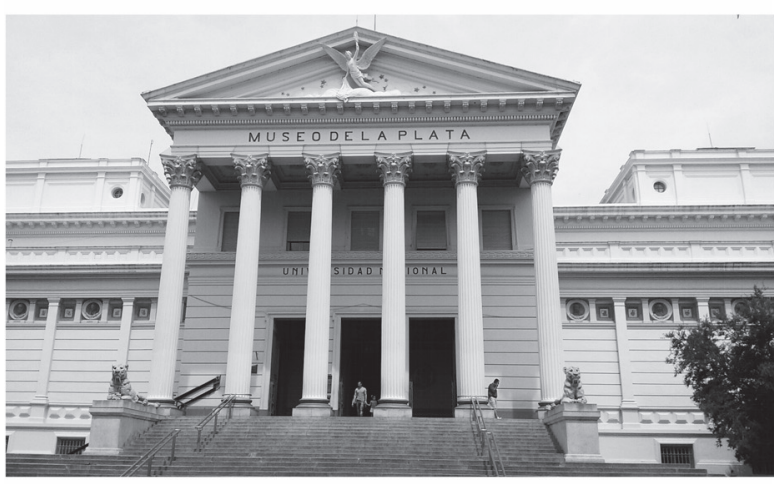

a

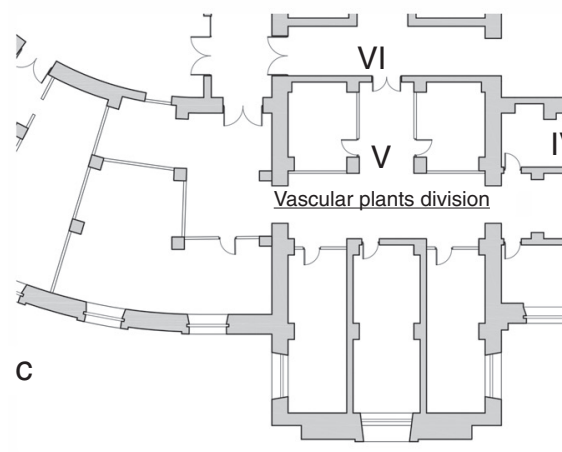

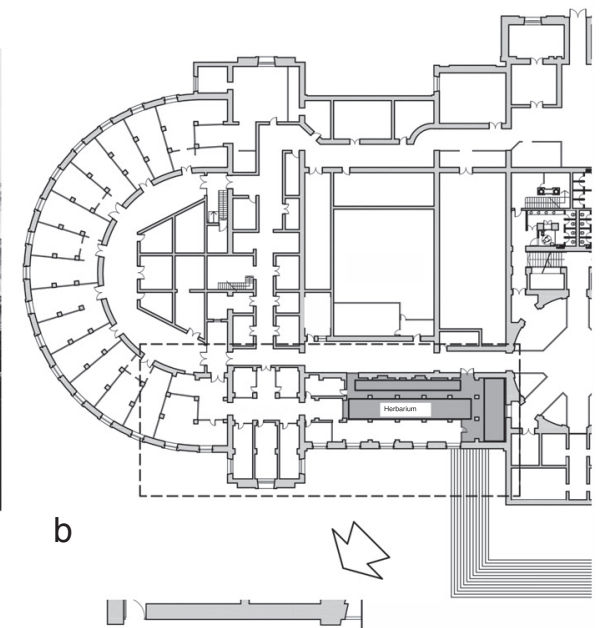

$\square \longleftarrow$
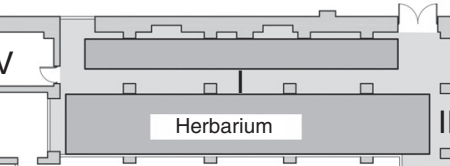

$\sqcup \frac{\square \square \square}{\square}$

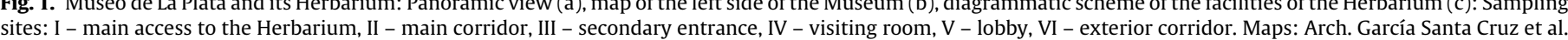
Laboratorio de Arquitectura y Hábitat Sustentable, Universidad Nacional de La Plata.

sampling procedures were standardized at the same air flow and time of sampling for comparison of results. The sampling was carried out for $5 \mathrm{~min}$ at $1.5 \mathrm{~m}$ high in the center of the rooms.

Briefly, in the non-viable system the air stream is accelerated by the suction pump at a flow of $15 \mathrm{l} / \mathrm{min}$ and impacts on a glass slide that contains a sticky and optically clear sampling medium which collects and holds bioaerosols and inert particles. The glass cover slip containing the sample traces was removed from the Air-O-Cell ${ }^{\circledR}$ cassette and mounted on a slide, then stained with lactophenol cotton blue and covered with a slip. These samples were observed using an Olympus $\mathrm{BH} 2$ microscope at a magnification of $400 \times$ along seven transverse lines covering $22 \%$ of the total area of the preparation. Likewise, a magnification of $1000 \times$ was used in some cases to achieve an accurate identification. Different bioaerosols, including sexual and asexual fungal spores, were detected and identified with reference atlases of the Kingdom Fungi and related ones, $3,18,24,28,39$ as well as with a specialized electronic database. ${ }^{7}$ Aerosol counts were then converted into elements per $\mathrm{m}^{3}$ air following Baxter. ${ }^{4}$

Since environmental dust may be a source of nutrients and support for the development of fungal microorganisms, the inert particle content in the air was analyzed counting the particles by means of the non-viable system. The criteria of the American Conference of Governmental Industrial Hygienists on Total Suspended Particulates (TSP $<100 \mu \mathrm{m}$ ) was applied for particles of inorganic origin like opaque particles and hyaline fibers and of human origin like skin cell fragments. ${ }^{28}$ Particle counting and estimation of concentration were made by the same methodology as that used for non-viable bioaerosols.

In the case of culturable-air sampling, the cassette was replaced by a sterile holder with a GE Osmonics mixed-cellulose ester filter of $0.43 \mu \mathrm{m}$ pore and $25 \mathrm{~mm}$ diameter and the resulting system was applied to the pump for $5 \mathrm{~min}$ for each sample at a rate of
$15 \mathrm{l} / \mathrm{min}$. After sampling, in the laboratory, each filter was suspended in $50 \mathrm{ml}$ of sterile water under aseptic conditions and the resulting suspension was vigorously shaken ( $15 \mathrm{~min}$ at $2000 \mathrm{rpm}$ ). To recover the greatest amount of fungal propagules adsorbed on the capture surface, the filter and aliquots $(1 \mathrm{ml})$ of the suspension as well as its decimal dilutions $(1: 10 ; 1: 100)$ were spread onto plates containing a $2 \%(\mathrm{w} / \mathrm{v})$ Corn Meal Agar (CMA) medium amended with glucose $\left(2 \mathrm{gl}^{-1}\right)$, chloramphenicol $\left(50 \mathrm{mg} \mathrm{l}^{-1}\right)$ and streptomycin (100 $\left.\mathrm{mg} \mathrm{l}^{-1}\right)$. This medium is broadly used for recovery of fungi from several types of samples such as soil, litter and air. $8,40,42$

The plates were incubated at $25^{\circ} \mathrm{C}$ and $63 \% \mathrm{HR}$ in the dark until colony development. After one week, colonies which had developed on each plate were counted (Colony Forming Units, CFU), analyzed microscopically, and identified taxonomically, based on cultural and morphological features. ${ }^{11}$ The CFU recovered from each sample were then converted into volumetric units calculated as: number of colonies $\mathrm{x}$ volume dilution/volume of air sampled. Furthermore, some representative fungi were isolated in axenic culture. Stock cultures of these isolates were kept at $4{ }^{\circ} \mathrm{C}$ on $2 \%$ $\left(w^{-1}\right)$ malt extract-agar slants, and then deposited in the culture collection of the Instituto Spegazzini, Universidad Nacional de La Plata, La Plata, Argentina (LPSC).

On the data obtained from both sampling procedures, the specific prevalence ${ }^{48}$ and species richness ${ }^{32}$ of each taxon were estimated. The indoor/outdoor index was also estimated. ${ }^{31}$

\section{Results}

Sample analysis using the non-viable method

Ten spore morphotypes from fungal and related sources, one fern spore type and one pollen grain type were found as biological 
Table 1

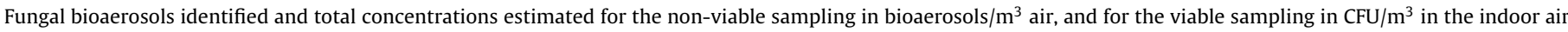
of the LP Herbarium.

\begin{tabular}{|c|c|c|c|c|c|c|c|}
\hline Spore type (non-viable system) & SI & SII & SIII & SIV & SV & SVI & Total count \\
\hline Alternaria & & & & & & 238 & 238 \\
\hline Arthrinium & & & & & & 59 & 59 \\
\hline Aspergillus/Penicillium & & & 953 & & & 59 & 1013 \\
\hline Ascospores & & & & 119 & 59 & & 178 \\
\hline Chaetomium & & & & & & 59 & 59 \\
\hline Cladosporium & & & 178 & & & 1609 & 1788 \\
\hline Dreschlera/Bipolaris & & & & & 178 & & 178 \\
\hline Epicoccum & & & & & & 59 & 59 \\
\hline Leptosphaeria type & & & 59 & & 59 & 119 & 238 \\
\hline Myxomycota & & & & 59 & & 298 & 357 \\
\hline Pollen & & & & & 59 & & 59 \\
\hline Fern spores & & & & & 178 & & 178 \\
\hline Total part $/ \mathrm{m}^{3}$ air & & & 1192 & 178 & 536 & 2504 & 4411 \\
\hline Indoor/outdoor index & & & 0.48 & 0.07 & 0.21 & & \\
\hline Fungal taxa (viable system) & SI & SII & SIII & SIV & SV & SVI & Total count \\
\hline Acremonium & 500 & & & & & & 500 \\
\hline Alternaria alternata & & 500 & 2000 & & & 500 & 3000 \\
\hline Cladosporium cladosporioides & 1500 & & & 500 & 1500 & 500 & 4000 \\
\hline Cladosporium herbarum & & & & & & 500 & 500 \\
\hline White yeast & & & 500 & & & 500 & 1000 \\
\hline Penicillium frequentans & & & & & & 500 & 500 \\
\hline Penicillium rubrum & & & & & & 500 & 500 \\
\hline Penicillium thomii & 500 & & & 1500 & & 500 & 2500 \\
\hline Rhodotorula sp. & & & 27,500 & & & 500 & 28,000 \\
\hline Total part $/ \mathrm{m}^{3}$ air & 2500 & 500 & 30,000 & 2000 & 1500 & 4000 & 40,500 \\
\hline Indoor/outdoor index & 0.63 & 0.13 & 7.50 & 0.50 & 0.38 & & \\
\hline
\end{tabular}

Table 2

Type and concentrations of inert particles (particles $/ \mathrm{m}^{3}$ air) estimated in the indoor air of the LP Herbarium.

\begin{tabular}{|c|c|c|c|c|c|c|c|}
\hline Inert particles & SI & SII & SIII & SIV & SV & SVI & Total count \\
\hline Skin cell fragments & 1013 & 8048 & 5842 & & 5723 & 775 & 21,403 \\
\hline Hyaline fibers & 1311 & & 4709 & 417 & 1192 & & 7631 \\
\hline Opaque particles & 59 & 1669 & & 715 & 536 & 59 & 3040 \\
\hline Total & 2384 & 9777 & 10,552 & 1132 & 7452 & 834 & 32,135 \\
\hline
\end{tabular}

dispersal units in the samples analyzed (Table 1). Other dusty particles such as skin cell fragments, hyaline fibers, and opaque particles, were also identified (Table 2). Total aerosol count converted into elements per $\mathrm{m}^{3}$ air corresponding to all the sites sampled showed a total of 4401.88 biological spores and 32135.18 total suspended particles (TSP).

Regarding the spore concentration, no spores were found in the main access (I) or in the central corridor (II) of the rooms containing the collections. In contrast, the secondary entrance (III) showed a concentration of around 1200 units $/ \mathrm{m}^{3}$, where Aspergillus/Penicillium and Cladosporium spore types were prevalent. In the visiting room (IV), the total concentration was of about 180 units $/ \mathrm{m}^{3}$ and the ascospore type was the most important. The total spore concentration in the lobby $(\mathrm{V})$ was 350 units $/ \mathrm{m}^{3}$ and Dreschlera/Bipolaris was the most important type. Also fern spores and pollen grains were found. Finally, the highest concentration of spore types was found in the exterior corridor (VI), with around 2500 units $/ \mathrm{m}^{3}$ (Fig. 2) and Cladosporium being the prevalent type (Table 1).

Regarding the results obtained in the sampling of inert particles (Table 2), skin cell fragments represented $67 \%$ of the total concentration, hyaline fibers $24 \%$ and opaque particles $9 \%$, being the central corridor (II) and the secondary entrance (III) the most affected by TSP.

Since the magnitude of the outdoor bioaerosol concentration might also be a determining factor affecting the indoor levels, an indoor/outdoor index was estimated for all interior sites and for individual sporal types, using the data obtained in the exterior corridor (VI) as an outdoor reference. The indoor/outdoor index in the

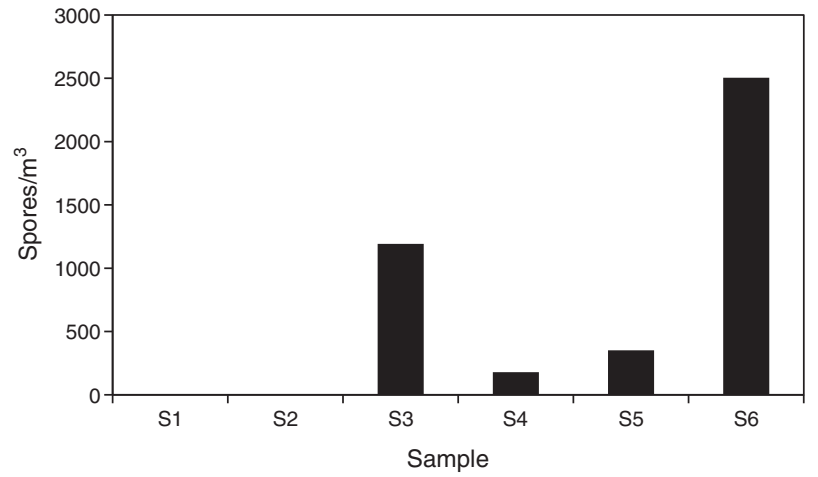

Fig. 2. Concentrations obtained by the non-viable method in the sampling sites (spores $/ \mathrm{m}^{3}$ air)

collection room was $0 \%$ in the main access (I) and central corridor (II) and $46 \%$ in the secondary entrance (III). Values for the visiting room (IV) and the lobby (V) were of $7 \%$ and $21 \%$ respectively (Table 1)

When the ratio was calculated for individual taxa (Table 1), four sporal types were present only in the exterior corridor (VI), two solely in the interior air of the Herbarium and four taxa both inside and outside (Fig. 3). 


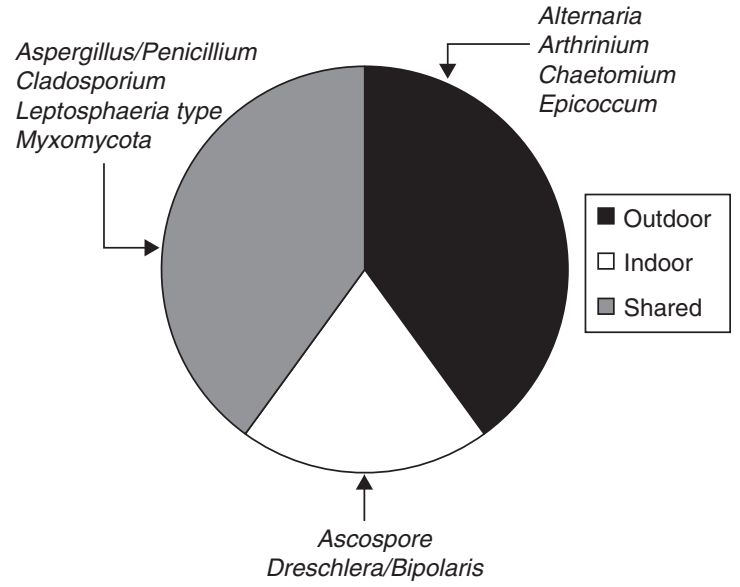

Fig. 3. Typical spores found by the non-viable method, inside the Herbarium, outside the Herbarium and in both sites.

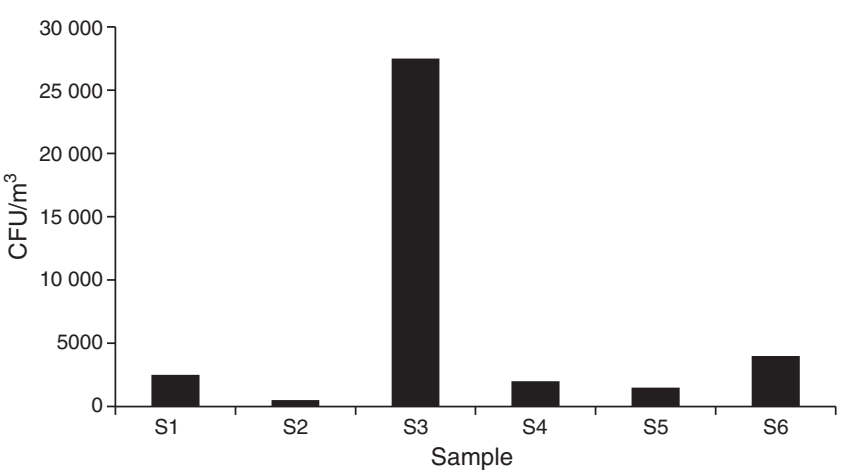

Fig. 4. Concentrations obtained by the viable method in the sampling sites (CFU $/ \mathrm{m}^{3}$ air).

\section{Sample analysis using the viable method}

Nine fungal taxa were identified as viable spores when different air samples from the LP Herbarium were applied as inoculum source on an agar medium (Table 1 ). Although several decimal dilutions of up to $1: 10^{3}$ were spread on agar plates, only informative data were obtained in the sampling of their own filter and the non-diluted suspension ( $\leq 40$ CFU per plate).

The total estimated count of fungal $\mathrm{CFU} / \mathrm{m}^{3}$ air showed 40500 elements for all the sites sampled.

Regarding the total concentration, $2500 \mathrm{CFU} / \mathrm{m}^{3}$ air were estimated for the main access (I), where Cladosporium cladosporioides (Fresen.) G.A de Vries, was the most important type. The central corridor (II) showed the lowest value, with $500 \mathrm{CFU} / \mathrm{m}^{3}$ and Alternaria alternata (Fr.) Keissl, being the main type. The secondary entrance (III) had the highest concentration, with $30,000 \mathrm{CFU} / \mathrm{m}^{3}$, mainly represented by Rhodotorula F.C. Harrison.

In the visiting room (IV) $\left(2000 \mathrm{CFU} / \mathrm{m}^{3}\right)$, Penicillium thomii Maire, was the most important taxon being close to Penicillium frequentans Westlingbut (Fig. 4).

When each spore type was considered, Rhodotorula sp. F.C. Harrison, C. cladosporioides (Fres.) de Vries and Cladosporium herbarum (Pers.) Link, were the most prevalent taxa. Similarly to the data obtained using the non-viable method, the exterior corridor (VI) showed the highest richness of airborne fungal propagules (Fig. 5).

When the ratio was calculated for individual taxa in the viable method (Table 1), three spore types were present in the exterior corridor (VI), one solely in the interior air of the Herbarium and four taxa both inside and outside (Fig. 6).

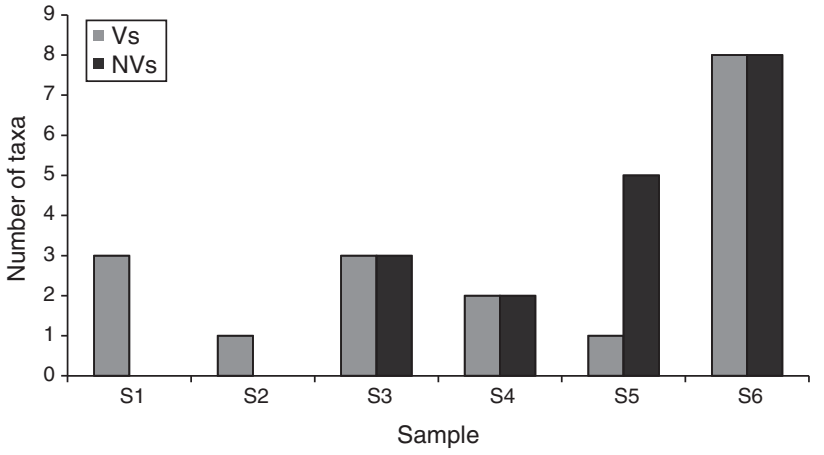

Fig. 5. Comparison of the richness of taxa obtained by the viable and non-viable methods in the sampling sites. V, viable method; NV, non-viable method.

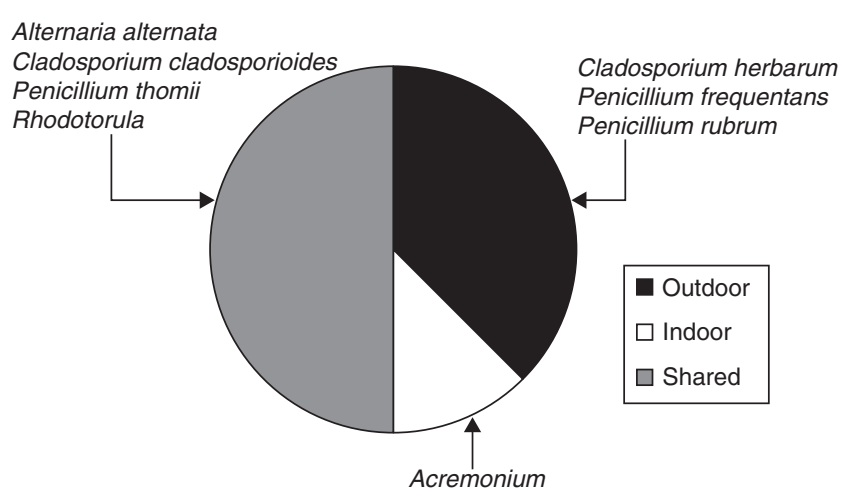

Fig. 6. Typical spores found with the viable method, inside the Herbarium, outside the Herbarium and in both sites.

\section{Discussion}

In this study, a preliminary analysis of the indoor air quality in six sectors of the LP Herbarium was done using a volumetric system for both viable and non-viable samples. Although a differential richness of spores and/or other airborne elements was found, it was dependent on each methodology applied. In this sense, the viable method was the most efficient in the identification of fungal taxa. While three fungal representatives were captured from sites I and II, the non-viable one did not record any fungal spore in those sectors. However, the apparent absence of propagules from one sampling type cannot discard their existence in the environment, when they are detected using another method. This fact is closely related to the existence of specific limitations for each type of sampling, being the morphological alteration and the viability and physiological requirements (including nutritional ones) the critical aspects for the non-viable and viable methods respectively. ${ }^{43}$ Trunov et al. ${ }^{49}$ suggested that disaggregated spherical spores, such as those belonging to Aspergillus and Penicillium, can be damaged by mechanical stress during their collection and be transformed to particulate elements that hinder their diagnosis and therefore their identification. On the other hand, the viable method also can fail when spore viability is affected and/or when the culture medium used for the growth of the air samples is not suitable. Although Aspergillus/Penicillium-type and Chaetomium-type spores were found in the secondary entrance and/or the exterior corridor, respectively, none of these taxa developed on an agar medium for fungi when samples from the viable method were inoculated.

While the two methods used in this work recovered a similar number of fungal spores, the taxa were different in each case (Figs. 3, 5 and 6). Only spores related to the genera Alternaria Nees and Cladosporium Link were detected by both methods. However, the non-viable method, which detected a higher number of 
taxa than the viable method, is also useful for the identification and quantification of some ascospores, basidiospores and other propagules that show specific difficulties to germinate. ${ }^{37}$ Both Aspergillus-Penicillium-type and Cladosporium-type spores were the ones that showed the highest relative concentration (23 and $40 \%$, respectively) in comparison to the other types identified by the non-viable method. This method also allowed the capture and detection of several inert particles, which might be important in air pollution since they may be vehicle and/or substrate for microorganisms. ${ }^{15,22,41}$ Similarly, other authors have reported a higher number of airborne fungi using the non-viable method. ${ }^{1,2,7}$ In contrast, the viable method allows the accurate identification of most anamorphic fungal species such as those which require culture methods.

An indoor/outdoor ratio $\geq 0.63$ and concentrations of bioaerosols $\geq 2500$ part $/ \mathrm{m}^{3}$ air were found in the samples from sites I and II. Although there are no international standards for indoor air quality regarding bioaerosols, our results suggest a safe air quality in the conservation areas of the LP Herbarium according to the findings of several authors. ${ }^{17,31,34}$ Additionally, although several taxa and/or morphological types were identified in the indoor air of the LP Herbarium by means of both methodologies, none of the samples analyzed included representatives of Stachybotrys Corda, Fusarium Link, Trichoderma Pers., or Aspergillus versicolor (Vuill.) Tirab, which are generally regarded as indicators of moisture problems. ${ }^{9,34}$ Therefore our results are compatible with a safe conservation for cultural heritage such us Herbarium material. However, most fungal types and taxa that we found in the Herbarium, such as Penicillium and Cladosporium, are ubiquitous fungal elements in indoor air. ${ }^{23,53}$ On the other hand, higher richness and concentration of airborne elements were found in site VI (exterior corridor), probably due to the proximity to the exterior and/or the movement of the staff within the Museum. Furthermore, the secondary entrance, which showed a higher indoor/outdoor index for the culturable sample, is also amenable to aerobiological contamination, possibly due to the fact that it is a crossing point between the Herbarium and the outside world, and it is frequently used to access to the collections. In this sense, Rhodotorula sp., which was detected only in this site (secondary entrance) using the viable method, was the element with the highest relative concentration, in comparison to others also identified (Table 1). Although Rhodotorula is a common environmental yeast that may be found in several contexts-including the air-, colonizing plants, humans, and other mammals, it has been recently recognized as an emerging pathogen in immunosuppressed patients, and the number of infections it causes has increased along the time. ${ }^{50,52}$ The presence of this fungus in association to a high level for an individual bioaerosol (not detected in the exterior corridor) suggests that the main source comes from within, for example from human origin. ${ }^{31}$ Everyday activities in the Herbarium such as handling organic materials, resuspension of spores as a result of cleaning activities, and the transportation of spores in the clothes, ${ }^{30}$ plus the movement of the air and the relative humidity, could help to explain the results obtained.

In conclusion, both sampling methods were necessary to monitor the bioaerosol charge in the LP Herbarium. Under the environmental conditions in which this institution was analyzed, the status in this indoor air seems to be rationally adequate for the conservation of Vascular Plants due to the low indoor/outdoor index, low concentrations of airspora and lack of taxa indicator of moisture problems, at least in sites I and II, where the plants are conserved. Similar results were obtained during the same season of sampling in a neighboring repository of mummified legacy from the Museo de La Plata. ${ }^{39}$ Therefore, although preliminary, our results may be applied for the diagnosis and prevention of the potential effects of airborne fungi in biodeterioration since under certain climatic conditions such as high humidity and precipitation, their explosion and activity may be relevant. ${ }^{10}$

These findings are important since there are scarce available data or systematic studies on the quality of the indoor air in La Plata Museum and the incidence of bioaerosols, including fungi, which can potentially cause adverse health effects. ${ }^{39}$ This information should have priority treatment to evaluate the need of measures for the proper handling of materials, and to take any additional action to control the conditions and safe preservation of the plant collections of the LP Herbarium and other similar institutions.

Sources: Maps of the Museo de Ciencias Naturales and Herbarium LP by Arch. Mauro García Santa Cruz, Lic. Jimena García Santa Cruz and Arch. Analía Gómez Laboratorio de Arquitectura y Hábitat Sustentable, Facultad de Arquitectura y Urbanismo Universidad Nacional de La Plata.

\section{Conflict of interest}

The authors declare no conflict of interest.

\section{Acknowledgements}

The authors wish to thank architect Mauro García Santa Cruz, lic. Jimena García Santa Cruz and architect Analía Gómez, from the Laboratorio de Arquitectura y Hábitat Sustentable, Facultad de Arquitectura y Urbanismo, Universidad Nacional de La Plata, Museo de Ciencias Naturales and Herbarium LP for drawing the maps of the Museum and Herbarium.

The authors wish to thank Dr. Pedro Balatti for his generous advice on the development of the viable method. We are grateful to Dr. Jorge Crisci for allowing us to carry out this study in the LP Herbarium, to its curator, lic. Laura Iharlegui for her assistance, and to Dr. Marta A. Morbelli for her unconditional support.

This study was supported by grants from the Consejo Nacional de Investigaciones Científicas y Tecnológicas (CONICET), PIP 112200801-01412, PIP 112-200801-01085, PIP 112-201101-00381, PIP 112-201101-00087, PIP 112-20110100391; Foncyt: PICT 20130148, PICT 501, and Facultad de Ciencias Naturales y Museo, Universidad Nacional de La Plata (N581). Lic. Andrea C. Mallo belongs to the Comisión de Investigaciones Científicas de la Provincia de Buenos Aires CIC. PBA and Dr. Lorena Elíades, Dr. Daniela S. Nitiu and Dr. Mario Saparrat are researchers from CONICET.

\section{References}

1. Adhikari A, Sen MM, Gupta-Bhattacharya S, Chanda S. Airborne viable, nonviable, and allergenic fungi in a rural agricultural area of India: a 2-year study at five outdoor sampling stations. Sci Tot Environ. 2004;326:123-41.

2. Almaguer M, Aira MJ, Rodríguez Rajo FJ, Rojas TI. Study of airborne fungus spores by viable and non viable methods in Havana, Cuba. Grana. 2013;52:289-98.

3. Barnet HL, Hunter BB. Illustrated genera of imperfect fungi. New York: MacMillan Publ. Co.; 1987.

4. Baxter A. On line document Air O Cell Interpretation guide. Last update on January 2013. Environmental Analysis Association; 2006.

5. Borrego S, Guiamet P, Gómez de Saravia S, Batistini P, García M, Lavin P, et al. The quality air at archives and the biodeterioration of photographs. Int Biodeterior Biodegrad. 2010;64:139-45.

6. Bridson D, Forman L, editors. The herbarium handbook. Kew, UK: The Board of Trustees of The Royal Botanic Gardens; 1992. p. 93.

7. Burge HP, Boise JR, Rutherford JA, Solomon WR. Comparative recoveries of airborne fungus spores by viable and non-viable modes of volumetric collection. Mycopathologia. 1997;61:27-33.

8. Cabello MN, Arambarri AM. Diversity in soil fungi from undisturbed and disturbed Celtis tala and Scutiabuxifolia forests in the eastern Buenos Aires province (Argentina). Microbiol Res. 2002;157:115-25.

9. Chapman JA. Stachybotrys chartarum (chartarum = atra =alternans) and other problems caused by allergenic fungi. Allergy Asthma Proc. 2003;24:1-7.

10. D’Arcy N, Canales M, Spratt DA, Lai K. Healthy schools: standardization of culturing methods for seeking airborne pathogens in bio-aerosols emitted from human sources. Aerobiologia. 2012;28:413-22. 
11. Domsch KH, Gams W, Anderson T. Compendium of soil fungi. Eching, Germany: IHW-Verlag; 1993.

12. Fazio AT, Papinutti L, Gómez BA, Parera SD, Rodríguez Romero A, Siracusano G, et al. Fungal deterioration of a Jesuit South American polychrome wood sculpture. Int Biodeterior Biodegrad. 2010;64:694-701.

13. Florian MLE. Heritage eaters: insects and fungi in heritage collections. London: James \& James (Science Publishers) Ltd.; 1997.

14. Florian MLE. Water, heritage photographic materials and fungi. Top Photogr Preserv. 2003;10:60-73.

15. Gallo F, Valenti P, Colaizzi P, Sclocchi MC, Pasquariello G, Scorrano M, et al. Research on the viability of fungal spores in relation to different microclimates and materials. In: International Conference on Conservation and Restoration of Archive and Library Materials, vol. 1. 1996. p. 177-93.

16. Giraldo Castrillón M. Aislamiento de hongos celulolíticos causantes del biodeterioro de la Biblioteca Central de la Universidad del Valle (Cali-Colombia). Rev Mex Micol. 2009;29:9-14.

17. Gots RE, Layton NJ. Indoor health background levels of fungi. J Occup Environ Hyg. 2003;64:427-38.

18. Grant Smith E. Sampling and identifying allergenic pollens and molds. San Antonio, TX: Blewstone Press; 1990.

19. Gutiérrez DG, Katinas L, Torres Robles SS. Material tipo de Carlos L. Spegazzini en el herbario del Museo de La Plata (LP), Argentina. II: Fabaceae. Darwiniana. 2002;40(1-4):77-101.

20. Hidalgo Y, Borrego S. Aislamiento y caracterización de hongos en documentos de la Biblioteca Nacional José Martí; 2006. http://www.bnjm.cu/rev_biblioteca/ bibliotecas_2006/pages/articulo6.htm

21. Hidalgo Y. Aislamiento y caracterización de hongos en documentos de la Biblioteca Nacional José Martí. Bibliotecas. An Investig. 2006;2.

22. Hsing J, Milton CH, Schwartz DK, Burge HA. Dust borne fungi in large office buildings. Mycopathologia. 2001;154:93-106.

23. Hyvärinen A, Vahteristo M, Meklin T, Jantunen M, Nevalainen A, Moschandreas D. Temporal and spatial variation of fungal concentrations. Indoor Air Aerosol Sci Technol. 2001;35:688-95.

24. Käärik A, Keller J, Kiffer E, Perreau J, Reisinger O. In: Nilsson S, editor. Atlas of airborne fungal spores in Europe. Berlin: Springer-Verlag; 1983.

25. Kanaani H, Hargreaves M, Ristovski Z, Morawska L. Deposition rates of fungal spores in indoor environments, factors affecting them and comparison with nonbiological aerosols. Atmos Environ. 2008;42:7141-54.

26. Katinas L. Material Tipo de Carlos L. Spegazzini en el Herbario del Museo de La Plata (LP), Argentina. III. Darwiniana. 2004;42(1-4):177-200.

27. Klich MA. Health effects of Aspergillus in food and air. Toxicol Ind Health. 2009;25(9-10):657-67.

28. Lacey ME, West JS. The air spore. Dordrecht, Netherlands: Springer; 2006.

29. Lee HS, Kang BW, Cheongs JP, Lee SK. Relationships between indoor and outdoor air quality during the summer season in Korea. Atmos Environ. 1997:31:1689-93.

30. Lehtonen M, Reponen T. Everyday activities and variation of fungal spore concentrations in indoor air. Int Biodeterior Biodegrad. 1993;31:25-39.

31. Levetin E, Shaughnessy R, Fisher E, Ligman B, Harrison J, Brennan T. Indoor air quality in schools: exposure to fungal allergens. Aerobiologia. 1995;11:27-34.

32. Magurran AE. Ecological diversity and its measurement. London: Croom Helm; 1988.

33. Maroni M, Seifert B, Lindvall T, editors. Indoor air quality: a comprehensive reference book. Air quality monographs, vol. 3. Elsiever; 1995.

34. Michelsen A, Pinzari F, Barbabietola N, Piñar G. Monitoring the effects of different conservation treatments on paper-infecting fungi. Int Biodeterior Biodegrad. 2012;30:1-9.
35. Muro Cacho CA, Stedford T, Banasik M, Suchecki TT, Persad AS. Mycotoxins: mechanisms of toxicity and methods of detection for identifying exposed individuals. J Land Use Sci. 2004;19:537-45.

36. Mycology [Online]. http://www.mycology.adelaide.edu.au [accessed 17.03.14].

37. Nayar TS, Jothish PS. An assessment of the air quality in indoor and outdoor air with reference to fungal spores and pollen grains in four working environments in Kerala, India. Aerobiologia. 2013;29:131-52.

38. Nitiu DS, Mallo AC, Gardella Sambeth MC, Morbelli MA. Contribución a la identificación de esporas del Reino Fungi en la atmósfera de La Plata (Argentina). Bol Soc Arg Bot. 2010;45(3-4):301-8.

39. Nitiu DS, Mallo AC, Elíades LA, Saparrat ME, Vazquez HR. Monitoreo de la carga fúngica ambiental y de otros bioaerosoles en un depósito de restos momificados del NOA del Museo de La Plata (Argentina). Bol Soc Arg Bot. 2015;50: 427-36.

40. Pancotto VA, Sala OE, Cabello M, López NI, Robson M, Ballare CA, et al. Solar UV-B decreases decomposition in herbaceous plant litter in Tierra del Fuego, Argentina: potential role of an altered decomposer community. Glob Change Biol. 2003;9:1465-74.

41. Petushkova J, Kandyba P. Aeromicrobiological studies in the Moscow cathedrals, Aerobiologia. 1999;15:193-201.

42. Punnapayak H, Sudhadham M, Prasongsuk S, Pichayangkura S. Characterization of Aureobasidium pullulans isolated from airborne spores in Thailand. J Ind Microbiol Biotechnol. 2003;30:89-94.

43. Pyrri I, Kapsanaki-Gotsi E. A comparative study on the airborne fungi in Athens, Greece, by viable and non-viable sampling methods. Aerobiologia. 2007;23:3-15.

44. Saparrat MCN, Estevez JM, Troncoso MI, Arambarri AM, Balatti PA. In-vitro depolymerization of Scutia buxifolia leaf-litter by a dominant Ascomycota Ciliochorella sp. Int Biodeterior Biodegrad. 2010;64:262-6.

45. Sequeira S, Cabrita EJ, Macedo MF. Antifungals on paper conservation: an overview. Int Biodeterior Biodegrad. 2012;74:67-86.

46. Simmon Nobbe B, Denk U, Poöll V, Rid R, Breitenbach M. The spectrum of fungal allergy. Int Arch Allergy Immunol. 2008;145:58-86.

47. Simmons JE, Muñóz-Saba Y, editors. Cuidado, manejo y conservación de las colecciones biológicas, Serie Manuales de campo. Conservación Internacional. Universidad Nacional de Colombia; 2005.

48. Soldevilla Agreda J. 2nd National Study of Pressure Ulcer Prevalence in Spain, 2005: Epidemiology and definitory wound and patient variables. Gerokomos. 2006; 17:154-72.

49. Trunov M, Trakumas S, Willeke K, Grinshpun SA, Reponen T. Collections of bioaerosols particles by impaction effect of fungal spore agglomeration and bounce. Aerosol Sci Technol. 2001;35:617-24.

50. Tuon FF, Costa SF. Rhodotorula infection. A systematic review of 128 cases from literature. Rev Iberoam Micol. 2008;25:135-40.

51. Velikova T, Trepova E, Rozen T. The use of biocides for the protection of library documents: before and now. In: Méndez-Vilas A, editor. Science against microbial pathogens: communicating current research and technological advances. 2011. p. 152-3.

52. Wirth F, Goldani LZ. Epidemiology of Rhodotorula: an emerging pathogen. Interdiscip Perspect Infect Dis. 2012, http://dx.doi.org/10.1155/2012/465717. Article ID 465717, 7.

53. Xu Z, Yao M. Analysis of culturable bacterial and fungal aerosol diversity obtained using different samplers and culturing methods. Aerosol Sci Technol. 2011;45:1143-53. 